\title{
The Oxford and Cambridge graduates' medical clubs
}

\author{
JOHN PEEL, JAMES ROBINSON
}

\begin{abstract}
He may live without books-what is knowledge but grieving, He may live without hope-what is hope but deceiving, He may live without love-what is passion but pining, But where is the man who can live without dining?
\end{abstract}

The answer to Lytton's question is, certainly not in Oxford or Cambridge, where dining has always been an important setting for discourse, dialogue, and debate. Witness the profundity of the postprandial discussions that have taken place over the centuries and still continue in the college common rooms as the port circulates. So it was 100 years ago that a number of the leading Oxford and Cambridge doctors from the London teaching schools got together to discuss the foundation of graduate medical clubs. Though at the first meeting of the steering committee of the Cambridge club the suggestion surfaced that the founding club should be joined with that of the Oxford one, which was still embryonic, it was soon submerged. History does not recall whether a similar suggestion was made at any of the early meetings of the Oxford club. There is no doubt, however, that it would have been a mistake to attempt to unite the two clubs. Though maintaining the friendliest relations with each other ever since, and from time to time attending each other's functions, each has grown and prospered maintaining individual identity and characteristics.

\section{Cambridge}

Among the Cambridge contingent some doubters emerged, as they always will at the suggestion of any new project. Thus one Dr Page wrote, "I feel some doubt in my own mind as to the formation of a dining club only, and I should like to see an association of Cambridge medical graduates do something more worthy of themselves." What he considered more worthy is not recorded, but a meeting was held on 24 November 1882 at 6 Savile Row, London W1 to discuss the formation of a Cambridge graduates' medical club, similar to those already existing in Edinburgh (Aesculapian Club founded 1773) and Aberdeen (founded 1789). The same gentlemen met again one week later. The minutes read, "Several proposals were made to alter the resolutions agreed at the previous meeting. No definite decision was arrived at concerning any of them, and after much loss of time Drs Fowler and Stevenson were appointed secretaries and were asked to call upon Sir George Burrows and ask him to be president."

On 2 February 1883 at the house of the first president, 15 Cavendish Square, the committee met for the purpose of forming the club. Of the 22 present, 14 were from Gonville and Caius college, including the president. They agreed, "That the object of the club shall be to further the interest of the medical and natural sciences schools of the University of Cambridge, and to promote good fellowship amongst the graduates."

Two weeks later yet a third meeting was held. It was resolved that, "Members should join by invitation." On 30 April at 146 Harley Street, the first dinner was planned to take place on

King's College Hospital, London

SIR JOHN PEEL, KCVO, honorary consulting obstetrician and gynaecologist

St Bartholomew's Hospital, London

JAMES ROBINSON, FRCS, honorary consulting surgeon
27 June 1883 at the Marlborough Rooms, 307 Regent Street, London W1. The Duke of Devonshire, as chancellor of the University of Cambridge, was invited, but unfortunately was unable to attend because of ill health. Those present did include Dr Paget, regius professor of physic, Dr Porter, master of Peterhouse and vice chancellor of the university, together with 57 members. Fifteen courses were served at a cost of half a guinea (not including wines).

\section{Oxford}

The pioneering spirit for Oxford was Dr A B Shepherd, dean of St Mary's Hospital, who called a meeting of a few Oxford colleagues at 17 Great Cumberland Place, London, on Wednesday 12 March 1884 . There were nine present, and they agreed to form a club similar to those of Edinburgh, Aberdeen, and Cambridge. A committee of 15 was appointed and at its first meeting Dr Fincham was elected president, Dr J H Morgan became secretary, and Dr Selby Church was treasurer. The four vice presidents included Sir Henry Acland, FRS.

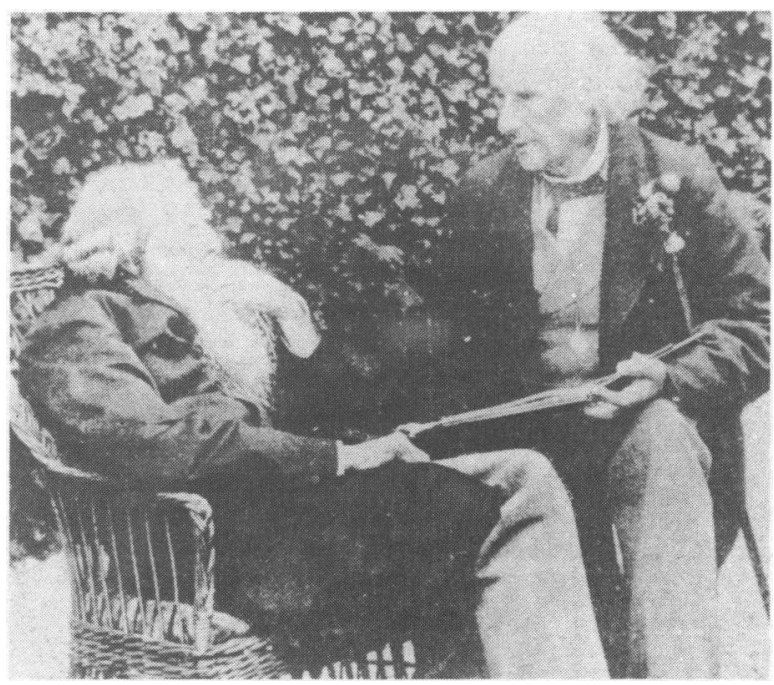

Acland in conversation with Ruskin

The inaugural dinner was held on 22 May 1884, and all Oxford graduates practising medicine were invited to attend. The dinner was held at Limmer's Hotel, 25 Conduit Street, London $\mathrm{W} 1$ and the price was $7 \mathrm{~s} 6 \mathrm{~d}$ a head. Owing to a mistake by the clerk at the hotel, the actual cost was $10 \mathrm{~s} 6 \mathrm{~d}$, but the treasurer agreed to pay the extra expense out of the funds of the club, though it seems likely that Dr Shepherd, a physician of some wealth, no doubt made a handsome personal contribution. The dinner consisted of 10 courses only, but rule 9 of the club laid it down that "the price of the dinner shall not exceed $7 \mathrm{~s} 6 \mathrm{~d}$ exclusive of wine." Forty eight members were present. Twelve rules were drawn up and approved, and have been changed very little ever since. It was agreed that the club should be essentially social rather than scientific, and rule 2 states that, "The objects of the club shall be to maintain associations with the university and to promote good fellowship among the members of the club."

It is of significance that these early meetings of both clubs 
took place in London rather than in Oxford or Cambridge. The Oxford medical school had been in decline during the first half of the nineteenth century and the average number of students taking the BM was two a year. With the arrival of Henry Acland as regius professor in 1857 things began to change. He believed that the university ought to provide an ideal scientific introduction to medicine, the students subsequently pursuing their clinical training in the London teaching hospitals. Acland was a great friend of Ruskin, and no doubt among the many subjects they talked about was the University Museum-“Ruskin's divine exhalation," which Acland built. The establishment of professorial departments of comparative anatomy, physiology, and human anatomy were also his achievements. From then on there was a steady increase in the numbers of students going to Oxford for their preclinical studies. It is an interesting sideline on contemporary attitudes that when Burdon Sanderson was Waynflete professor of physiology, before he became regius professor, he was frequently subjected to protest demonstrations by the antivivisection lobby.

The position in Cambridge was similar though the school there was never reduced to the small numbers of those at Oxford in the early part of the nineteenth century.

\section{Dining clubs}

As so many of the leading Oxford and Cambridge medical graduates held leading academic and clinical appointments in London, it was natural that they should wish to maintain their association with their own universities and colleges. A social dining club was an obvious starting point. It is interesting that both clubs quite independently arrived at the conclusion that membership of the club should be extended to medical graduates from other universities, provided that they became graduates of Oxford or Cambridge-hence the title "graduates' medical club."

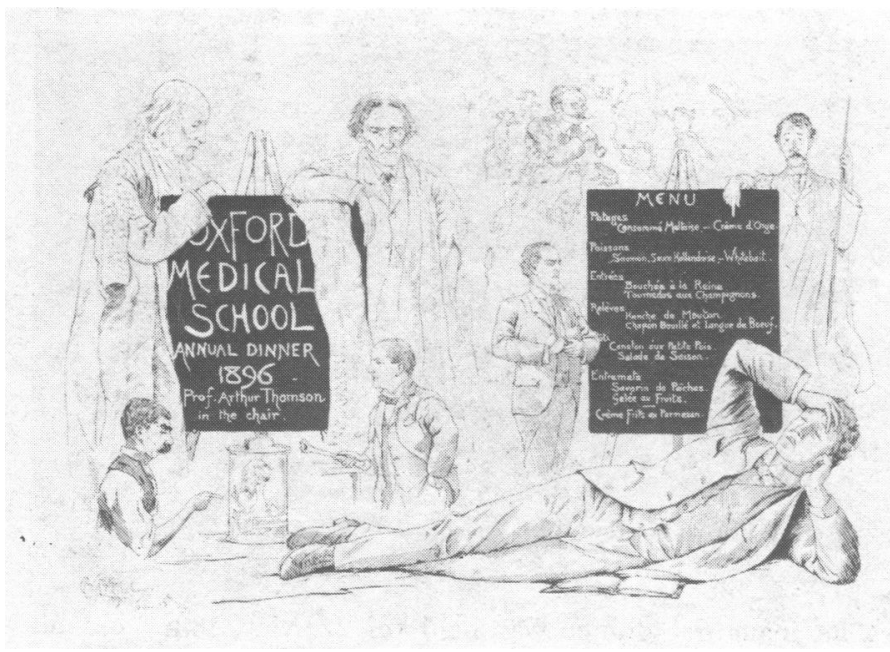

Though the primary objectives in both cases were social, there was always the underlying intention to further the interests of, and maintain a close association with, medical schools of the two universities. Indeed, a special meeting of the Cambridge club was called on 20 January 1887 to consider the following resolution: "That it is expedient that a committee be appointed whose duties shall be to consider from time to time the regulations relating to degrees in medicine in the University; to receive and consider suggestions for the improvement of medical education there; and to take such action that they deem necessary."

Similarly, the Oxford club has always taken an active interest in the academic activities of the medical school. It has always been favoured by succeeding regius professors. The first Oxford dinner was held in Christ Church on 31 May 1899, when the regius professor (John Burden Sanderson) took the chair. It was while working with him that a later president of the club, Sir Henry Souttar, recorded from a string galvanometer the first electrocardiographic tracings. In due course Osler, Garrod, and Farquhar Buzzard and their successors in more recent times, have all given not only their patronage but their active support and participation in the club's affairs. Many occasions have been honoured by the presence of chancellors and vice chancellors, and that great Oxford medical benefactor Lord Nuffield accepted honorary membership of the club in 1936. There was a time when the club sent two representatives to the academic board of studies in Oxford at its regular meetings.

Cambridge makes all its graduates eligible for membership and they may bring guests to their dinners, provided that they are medical graduates of another university. Ladies having the correct qualifications are welcomed, but wives and ladies without those qualifications are not eligible-at least until the recent centenary dinner at Trinity, when they appeared in great numbers and added much grace to a splendid occasion. Oxford has had much travail over the subject of the ladies. In 1922 a postal vote was taken on whether women graduates should be admitted to the club. The proposal was rejected by 71 to 52 votes. By 1956 a more liberal attitude prevailed and they became full members. Now the doors have been opened wide, and non-medical guests of either sex are made welcome.

\section{Venues}

A short account of a few of the early occasions reflects something of the contemporary pattern of entertainment common towards the end of the nineteenth century. The Limmer's Hotel was the London site for the Oxford club to meet regularly until 1900. In 1901 the first combined meeting with the Cambridge medical graduates' club took place in the Victoria Hall of the Hotel Cecil. In most cases after the dinner, a smoking concert was organised, with music, singing, and recitations by the members. It was arranged that a professional accompanist should be engaged at a fee not exceeding one guinea. A few years later this type of entertainment was changed to an after dinner visit to an adjoining picture gallery, where the minutes record that the atmosphere was chilly and the exhibits met with little approval. In 1888 an evening conversazione was held at the Marlborough Rooms in Regent Street. The evening's entertainment consisted of glees, and partsongs with a double male quartet; the total cost was just under $£ 50$ for 200 members.

Regular dinners continued to be held at different restaurants - the Trocadero, the Cafe Royal, Prince's, and the Hotel Cecil. At a special dinner at the Criterion in 1910 Sir William Osler was in the chair. The cost of the menu had by this time gone up to 15 shillings, but it consisted of oysters, turbot soup, mutton, sorbet, pheasant, ice pudding, and dessert. The wines consisted of sherry, Niersteiner, two champagnes, Dow's 1896 port, with liqueurs and minerals. A look through the speeches at these early dinners gives an interesting sketch of the Oxford medical events and shows the club's concern to keep up its association with the university. At a dinner in 1905 Osler gave it as his view that Oxford could never be a clinical, but must always be an essentially scientific school, and he hoped to add to the existing departments those of hygiene and pharmacology. After this dinner the club donated $£ 520$ towards the recent endowment of the chair of pathology.

The Cambridge club pursued a similar course. The Marlborough Rooms on 29 February 1884 were the venue for a Cambridge conversazione. Fifty six members attended and 76 guests, most being Cambridge graduates, but there were also some from Oxford. Music was played by some of the members and all were allowed to smoke. There were many exhibits including model railway signals moved by an electromagnet, old prints, the demonstration of a sonometer for "testing and 
accurately measuring variations of the sense of hearing," and instruments used in the experimental research of blood pressure.

By 1884 a council had been formed and a meeting was held under the chairmanship of Dr Norman Moore at the warden's house of St Bartholomew's Hospital Medical College.

The Holborn Restaurant was the venue of the 1885 dinner. Apparently a political discussion took place, for two speakers made adverse remarks about the proposition then before the medical profession that, "The Royal Colleges of Physicians and Surgeons should be united for the purpose of obtaining the powers to grant degrees." The following year the first dinner was held at Cambridge. As might be expected the college chosen was Gonville and Caius and Sir George Paget was in the chair.

Few things change. In 1919 Herbert Page, then president of the club sent his apologies, "to my very great regret I fear this damnable strike will prevent my being at the meeting."

Through the next two decades there were dinners in both London and Cambridge, but the emphasis has gradually and quite rightly shifted towards the university. Since the end of the second world war all dinners have been in Cambridge, now always on a statutory date on the second Friday in July. The principles as laid down at the first committee meeting in 1883 are still upheld. For many years the president of the club together with representatives of the Council, the regius professor of physic, and the deans from several medical colleges meet under the chairmanship and through the kindness of $\mathrm{Dr}$ Woollam for lunch at Emmanuel College on the day of the dinner. At this meeting the many problems which exist in medical education are discussed and though no resolutions are passed many views are exchanged and a deal of understanding generated. Above all the principle to promote good fellowship among the graduates has never been lost.

The Oxford club, though also tending to move its centre of gravity from London to Oxford, has continued to have winter dinners in London. The first to which non-medical guests were invited was a particularly memorable one in 1965 when the right honourable Harold Macmillan as chancellor was present and gave one of his usual scintillating speeches.

\section{Centenary}

Can one assess the real impact that these two clubs have made during their 100 years' existence on the medical schools and on the graduates? There can be no doubt that the annual social occasions have been popular and successful. For individual graduates to return regularly to the university, to meet with old friends and colleagues, to enter into discussions on all manner of subjects, and to share experiences, is in itself immensely worth while. It is not just sentimental nostalgia. That so many of the great men of medicine from both universities have been active participants in the affairs of the clubs and given $c^{f}$ their time and interests is in itself an acknowledgment of their value. Times have changed. Both universities now have well established clinical schools and academic departments. Graduates are now spread much more widely around the British Isles and overseas as well as in London. For all that the ties with the alma maters are as strong as ever. The recent magnificent centenary dinner at Trinity College, Cambridge, was attended by over 300 members and guests and no one who was there can doubt the viability of the club. The centenary dinner of the Oxford club will be at Keble College on 6 July 1984 .

The end of the first 100 years is not the end of the story. As the clubs enter their second century a regular entry of new young graduates is essential for their future viability. Happily this is taking place, but the more the better. Graduates who have not yet joined the clubs, but are interested, should communicate with the Honorary secretaries: Cambridge-W A B Smellie, MChir, 62 Gough Way, Cambridge CB3 9LN; Oxford-Dr R A Griffiths, FRCP, Long Ridges, The Ridings, Headington, Oxford OX3 8TB.

\section{Leonard Colebrook (1883-1967)}

\section{E J L LOWBURY}

The centenary this year of Leonard Colebrook's birth calls for celebration, for though he never became a "household name," his contributions to human welfare were outstanding. His classic work on the treatment of puerperal fever with Prontosil was both a major advance in obstetric practice and a pioneering exercise in antimicrobial chemotherapy. The work he undertook after completing that project was hardly less important, and also had both a specific target-improving the treatment of burns-and a more general beneficial influence-awakening an interest in control of hospital infection. Colebrook's endeavours for human health and wellbeing continued after his retirement when, with the collaboration of his wife, he launched an effective campaign to reduce the numbers of burn injuries.

Leonard Colebrook was born in Guildford, Surrey, on 2 March 1883, fifth of the six children of May and Mary Colebrook. May Colebrook was a successful farmer, a non-conformist preacher, and a local worthy. The Colebrooks' home was filled with "an atmosphere of education, religion, social work,

University of Aston in Birmingham, Birmingham B4 7ET

E J L LOWBURY, DM, FRCPATH, honorary visiting professor of medical microbiology and rigid teetotalism"'; exposed to these influences Leonard made up his mind early in life to become a missionary. In 1896 his father died and the family moved to Bournemouth. Leonard was sent to Westbourne High School and spent a year at Christ's College, Blackheath, before starting premedical studies at the London Hospital Medical College in 1900. A few months later he won an entrance scholarship to St Mary's Hospital, where he completed his medical studies, qualifying $\mathrm{MB}$, BS (London) in 1906. One of his fellow students was Alexander Fleming.

While still a student Colebrook came under the spell of Sir Almroth Wright, professor of pathology and founderdirector of the inoculation department of St Mary's. Wright was a charismatic figure, the pioneer of typhoid vaccination, whose interests and efforts in bacteriology were focused on the relief of human suffering: he was an independent minded and "savage" controversialist, a friend of Bernard Shaw and the original of Sir Colenso Ridgeon in A Doctor's Dilemma. After a period as house surgeon and a trip to the Far East as ship's doctor, Colebrook achieved his ambition of becoming assistant to Wright in the inoculation department. On his travels he discovered that a career in bacteriology was more to his taste now than that of a missionary. For Colebrook "the old man," as they called Wright in his department, was not only a chief whose ideas he admired, but a sort of adoptive father; though 